\title{
Sleep Quality of Elderly with Diabetes Mellitus
}

\author{
Citra Windani Mambang Sari, Upi Parida, Dian Adiningsih \\ Faculty of Nursing, Universitas Padjadjaran \\ Email:upi.parida@gmail.com
}

\begin{abstract}
Diabetes Mellitus (DM) is a chronical community health problem, and mostly suffered by the elderly. The elderly with DM have several symptoms at night that caused a sleep disorder and it may be affected by the poor quality of sleep. The poor quality of sleep has several negative impacts to elderly including sleepy in the daylight, a lack of attention, memory disorders, depression, easy to fall, and reduce of the quality of life. There is a need for a study that assesses the sleep quality of elderly with DM. This study used descriptive quantitative approach. The samples were chosen using total sampling technique. This study involved 47 elderly with DM in the primary health center (PHC) Garuda. The data were collected using Pittsburgh Sleep Quality Index (PSQI) Questionnaire that has been adapted for elders. The data were analyzed using distribution frequency. The results showed that the majority of elderly had a poor sleep quality $(51 \%)$. All elders in this study had sleep disorders, and some of them had behavior that affected their sleep quality, such as sleeping in a bright room $(n=25)$, sleeping in low temperature room $(n=27)$, and consuming caffeine $(n=28)$. Nurses in the community setting are expected to provide health education to maintenance a good sleep quality, such as the importance of sleeping in the dark and warm temperature room, and avoiding to consume caffeine.
\end{abstract}

Keywords: Diabetes Mellitus, Elderly, Sleep Quality. 
Citra Windani Mambang Sari : Sleep Quality of Elderly with Diabetes Mellitus

\section{Introduction}

The number of DM patients increases every year. One out of 11 adults in the world suffered from Diabetes Mellitus. 415 million people live with DM and the number is predicted to increase to 642 million by 2040 (IDF, 2015). The incidence of DM has increased in Indonesia. Indonesia is ranked 7th of DM incidence in the world. The number of DM patients in Indonesia was approximately 10 million people that spread throughout provinces (IDF, 2015). The Basic Health Research (Riskesdas) data presented that the number of DM patients in West Java was 418,110 people in 2013. In addition, the data of Bandung City Health Office revealed that DM patients in in Bandung were 31,689 in 2015. According to Riskesdas data (2013), the prevalence of DM increases as they are getting older.

The symptoms of elderly with DM including nocturia, restless leg syndrome and sleep apnea (Surani, Brito \& Ghamande, 2015). Nocturia is a condition that an individual has to wake at night one or more times to urinate. It may affect their sleep patterns. Patients reported nocturia as the main cause of sleep disorders (Surani, Brito \& Ghamande, 2015). Polyuria would cause nocturia, as the urine production increased and exceed the bladder capacity (Van, 2010).

Restless legs syndrome (RLS) is a sleep disorder associated with sensorimotor problems could be primary or secondary, especially when it associated with other health problems. High blood sugar in DM patients would cause nerve damage, and lead to diabetic neuropathy peripheral. Another contributor factor of RLS is damaging feet nerves and low legs nerves. An individual with the periodic leg movements problem has sleep time an hour less than normal people (Amir, 2007).

Obstructive Sleep Apnea (OSA) is a sleep apnea that caused by complete or partial obstructions of the upper airway. Obesity is a risk factor for obstructive sleep apnea and insulin resistance. Sleep apnea causes sleep disturbance and decreased sleep duration (Balachandran, Mokhlesi \& Shear, 2014).

There were two effects of sleep disorders which are the changing carbohydrate metabolism and endocrine system. The changing of the endocrine system include decreasing insulin sensitivity and increasing insulin resistance (Song, 2013). An individual who had experienced sleep disorder and sleep less than 7 hours/day have a higher risk of DM because of insulin resistance. Sleep disturbance is associated with a risk of DM, an individual who sleep less than four hours a night have a high risk glucose intolerance than an individual who has adequate sleep (Cuellar \& Sarah, 2008). DM patients with sleep disorders would experience leptin hormone hypersecretion and decreased the production of it. The condition would lead to increasing the food intake especially carbohydrates. Increasing carbohydrate intake is the predispose to obesity (Cunha, Zanetti \& Hass, 2008). These conditions indicated that there is a reciprocal relationship between diabetes mellitus and sleep disturbance (Black \& Hawks, 2008).

Sleep disorder influences the quality of sleep, sleep quality is the satisfaction of a person to sleep. A person with a good quality of sleep does not show tiredness, anxious, lethargic and apathetic, blackish around the eyes, swollen eyelids, red conjunctiva, low attention, headache, yawning, or sleepy. Sleep quality includes both quantitative and qualitative aspects of sleep, such as the duration of sleep, the time take to fall asleep, the frequency of awakening, and subjective aspects such as sleep well (Hidayat, 2007).

Sleep quality score is a score from respondents answer questions in the Pittsburgh Sleep Quality Index (PSQI) instrument. This instrument consists of 7 (seven) components, namely subjective sleep quality, sleep latency, sleep duration, daily sleep efficiency, sleep, the use of sleeping pills, and daytime dysfunction. Each component has 0-3 score range with 0 indicating no sleep difficulties and 3 indicating severe sleep difficulties. The score of the seven components than summed to get a total score. There are two criteria of total score: $\leq 5$ means a good sleep quality, and $>5$ means poor sleep quality. The advantages of PSQI are high validity and reliability (Buysse et al, 1998; Smyth, 2012). However, this PSQI instrument also has disadvantages such as respondents may have difficulties to fill in the PSQI questionnaire 
Citra Windani Mambang Sari : Sleep Quality of Elderly with Diabetes Mellitus

because of their limited understanding of the questionnaire. It may impact to less accurate of respondents' answer. Guiding respondents in filling the PSQI is necessary.

Previous studies found that DM patients who hospitalized in Ungaran Semarang regency mostly had a poor sleep quality (Umbarwanto, Susilo \& Aniroh, 2016). However, a comparative study in Yogyakarta found that the quality of sleep of the Hamlet Kajen elderly was better than Unit Budi Luhur, because they lived in a comfortable environment and closed to family (Nabil \& Sulistyarini, 2013). The study of DM patients who lives with families in the Johor PHC, Medan found that more than half of respondents were not able to sleep well (Dewi, 2011).

This study was different from the previous research because it focuses on DM patients aged 60-90 years using the modified PSQI questionnaire to minimize inadequate information from the elderly. This research conducted in the PHC Garuda. The PHC has the largest DM patients from 2015-2016 compared with other PHC in Bandung. Based on a preliminary study in the Garuda subdistrict, the elderly in this areas live with their family and they have a good sleep quality.

The reason for conducting this study because of a poor sleep quality influence glycemic control, and may cause other health disorders (Surani, Brito \& Ghamande, 2015). There are some serious effects of sleep disturbance in the elderly such as long daytime sleepiness, attention and memory disorders, depression, frequent of falls, improper use of hypnotics, and deterioration in the quality of life. Mortality rates, heart disease and cancer were higher in people who sleep more than 9 hours or less than 6 hours per day compared to people who sleep 7-8 hours per day (Amir, 2007).

Nurses have roles in assessing and planning interventions of patients with a sleep disorder. The roles of nurses should be supported by nurses' knowledge of sleep (Kozier, Glenora, \& Shirlee, 2011). The study literature found that studies of sleep quality in elderly with diabetes mellitus in PHC is limited. It is necessary to do a research on sleep quality in elderly with diabetes mellitus in PHC. The purpose of this study was to identify sleep quality in elderly with DM in PHC Garuda Bandung.

\section{Research Method}

This was a quantitative research with descriptive analysis techniques. The descriptive research is a method to determine the value of independent variables, either one or more variable without making a comparison or linking it (Kerlinger, 2007). Variable in this research is the sleep quality. Sub-variables of this study were subjective sleep quality, sleep latency, sleep duration, sleep efficiency, night sleep disturbances, use of sleeping pills, and disruption of dayto-day activities. Population in this research was elderly with Diabetes Mellitus in PHC Garuda Bandung. The number of samples was 47 elderly. The samples were chosen using total sampling technique.

The instrument in this study was the Pittsburgh Sleep Quality Index (PSQI) that has been adapted for the elderly by Smyth in 2012. The PSQI is an effective instrument to measure adult sleep quality and patterns. It distinguishes "sleep deprivation" from "good" sleep by measuring seven domains mentioned above (sub-variables). The score had scale $0-3$ where 3 reflects the negative extremes on the Likert Scale. Globally "5" or less shows "sleep deprivation". A recent information about the scoring score: if $5 \mathrm{~J}$ is incomplete or missing, then it is considered "0" (Buysse et al., 1998; Smyth, 2012). The PSQI instruments had Back-Translated by some linguists, who had a background as a lecturer and nursing education. The PSQI had internal consistency and reliability coefficient (alpha Cronbach) of 0.83 for seven components. This instrument used by many previous studies in various older adult/ elderly populations, internationally, and had high validity and reliability (Smyth, 2012).

The researcher was the data collector. The researcher visited respondents' house, the respondents' addresses informed by the PHC. The researcher explained the purpose of research and conducted the informed consent of the respondents by giving information verbally and asking respondents to fill in the approval form. Respondents were allowed 
Citra Windani Mambang Sari : Sleep Quality of Elderly with Diabetes Mellitus

to ask a question to the researcher. The data were analyzed using the descriptive analysis. The location of the study was in PHC Garuda Bandung City on March-June 2017.

\section{Research Results}

Characteristics respondents include gender, residence, education, occupation, working in a shift, history of the disease, room light, room temperature and caffeine consumption in the past one month. Table 1 presents the characteristic of respondents in this study.
Table 1 reveal that the majority of elderly were female $(72.3 \%)$, they attended primary education $(59.6 \%)$, had no history of other disease $(57 \%)$, sleeping in bright light $(53 \%)$, ordinary of room temperature $(70 \%)$, and avoiding to drink caffeine $(59.6 \%)$. The majority of them lived with family $(93.6 \%)$ and were not working $(83 \%)$. None of them working in shift.

Table 2 presents that almost a half of the respondents had a sleep latency of $\leq 15$ minutes and 16-30 minutes of $20(42 \%)$. $49 \%(n=23)$ of respondents had dysfunction of daily activity. In addition, more than a

Table 1 Characteristic of Elderly $(n=47)$

\begin{tabular}{|c|c|c|}
\hline Characteristic & Frequency (f) & Percentage (\%) \\
\hline \multicolumn{3}{|l|}{ Gender } \\
\hline Man & 13 & 27.7 \\
\hline Woman & 34 & 72.3 \\
\hline \multicolumn{3}{|l|}{ Residence } \\
\hline Alone & 3 & 6.4 \\
\hline With Family & 44 & 93.6 \\
\hline \multicolumn{3}{|l|}{ Education } \\
\hline Elementary & 28 & 59.6 \\
\hline Junior School & 11 & 23.4 \\
\hline Senior School & 7 & 15 \\
\hline University & 1 & 2 \\
\hline \multicolumn{3}{|l|}{ Occupation } \\
\hline Employment & 8 & 17 \\
\hline Unemployment & 39 & 83 \\
\hline \multicolumn{3}{|l|}{ Working in Shift } \\
\hline Without Shift & 8 & 100 \\
\hline \multicolumn{3}{|l|}{ History of Disease } \\
\hline Hypertension & 15 & 32 \\
\hline Arthritis & 4 & 9 \\
\hline Heart & 1 & 2 \\
\hline None & 27 & 57 \\
\hline \multicolumn{3}{|l|}{ Room Lighting } \\
\hline Bright & 25 & 53 \\
\hline Dim & 5 & 11 \\
\hline Dark & 17 & 36 \\
\hline \multicolumn{3}{|l|}{ Room Temperature } \\
\hline Warm & 7 & 15 \\
\hline Ordinary & 33 & 70 \\
\hline Cold & 7 & 15 \\
\hline
\end{tabular}


Citra Windani Mambang Sari : Sleep Quality of Elderly with Diabetes Mellitus

\begin{tabular}{lll} 
Caffeine consumption last month & & \\
Yes & 28 & 59.6 \\
No & 19 & 50.4 \\
\hline
\end{tabular}

Table 2 Components of Sleep Quality ( $n=47)$

\begin{tabular}{|c|c|}
\hline Components of Sleep Quality & Frequency \\
\hline
\end{tabular}

\begin{tabular}{lcc}
\hline Subjective Sleep Quality & 14 & 30 \\
Very Good & 25 & 53 \\
Good & 8 & 17 \\
Bad & & \\
Sleep Latency & 20 & 42 \\
$\leq 15$ minutes & 20 & 42 \\
$16-30$ minutes & 5 & 11 \\
$31-60$ minutes & 2 & 5 \\
$\geq 60$ minutes & & \\
Sleep Duration & 8 & 17 \\
$>7$ hours & 26 & 55 \\
6-7 hours & 9 & 19 \\
$5-6$ hours & 4 & 9 \\
$<5$ hours & & \\
Sleep Efficiency & 32 & 68 \\
$>85 \%$ & 13 & 28 \\
$75-84 \%$ & 1 & 2 \\
$65-74 \%$ & 1 & 2 \\
$<65 \%$ & & \\
Sleep Disorder & 37 & 79 \\
Score 5b-5j 1-9(1) & 10 & 21 \\
Score 5b-5j 10-18(2) & & \\
Usage Sleep Pills & 40 & 85 \\
Never on 1 last month & 7 & 15 \\
Less than 1time in a week & 10 & 30 \\
Disfunction Activities on Daytime & 23 & \\
Score no.7+no.8 0(0) & 14 & \\
Score no.7+no.8 1-2(1) & & \\
Score no.7+ no.8 3-4(2) & & \\
\hline
\end{tabular}

Table 3 The Sleep Quality of Elderly with DM $(n=47)$

\begin{tabular}{|c|c|c|}
\hline Sleep Quality & $\begin{array}{l}\text { Frequency } \\
\text { (f) }\end{array}$ & $\begin{array}{c}\text { Percentage } \\
(\%)\end{array}$ \\
\hline Good & 23 & 49 \\
\hline Poor & 24 & 51 \\
\hline
\end{tabular}


Citra Windani Mambang Sari : Sleep Quality of Elderly with Diabetes Mellitus

Table 4 Characteristics of Respondents and Sleep Quality

\begin{tabular}{|c|c|c|c|}
\hline \multirow[t]{2}{*}{ No } & \multirow[t]{2}{*}{ Variable } & \multicolumn{2}{|c|}{ Sleep Quality } \\
\hline & & Good & Poor \\
\hline \multirow[t]{3}{*}{1} & & Residence & \\
\hline & Alone & 2 & 1 \\
\hline & Live with Family & 22 & 22 \\
\hline \multirow[t]{3}{*}{2} & & Occupations & \\
\hline & Employment & 2 & 6 \\
\hline & Unemployment & 22 & 17 \\
\hline \multirow[t]{5}{*}{3} & & History of Other Desease & \\
\hline & Hipertention & 7 & 8 \\
\hline & Atritis & 0 & 4 \\
\hline & Heart Attack & 0 & 1 \\
\hline & None & 17 & 10 \\
\hline \multirow[t]{4}{*}{4} & & Room Lighting & \\
\hline & Bright & 9 & 16 \\
\hline & Dim & 3 & 2 \\
\hline & Dark & 12 & 5 \\
\hline \multirow[t]{4}{*}{5} & & Room Temperature & \\
\hline & Warm & 4 & 3 \\
\hline & Normal & 14 & 19 \\
\hline & Cold & 1 & 6 \\
\hline \multirow[t]{3}{*}{6} & & Caffeine 1last month & \\
\hline & Yes & 12 & 16 \\
\hline & No & 12 & 7 \\
\hline
\end{tabular}

half of respondents had a good sleep quality $25(53 \%)$ and had a sleep duration of 6-7 hours $55 \%(n=26)$. The majority of them $(68 \%)$ had sleep efficiency of $>85 \%$. Almost all respondents had sleeping disorder $79 \%$ $(\mathrm{n}=37)$. Respondents said they never use sleeping pills $(85 \%)$.

Table 3 presents the majority of elderly have a poor sleep quality (51\%). Table 4 shows that 22 elderly who live with the family have good sleep quality, while 22 of them who live had a have poor sleep quality. A total of 22 elderly with DM who do not work have good sleep quality. A total of 17 elderly had no history of other diseases, they had a good sleep quality. Elderly with DM had a poor sleep quality $(n=19)$ with normal room temperature. A total of 16 elderly who taking caffeine in the past month had poor sleep quality.

\section{Discussion}

This study found that the quality of sleep elderly with DM was in the poor category. The majority of elderly lives with their family, and a half of them had a poor sleep quality. The results of this study are different from previous research that stated the conditions of residence not affect to much to the quality of sleep. Previous research found that elderly who live in their home had a better quality of sleep, elderly felt more comfortable living in their own home with the family. That condition supports the maintenance of their sleep quality (Nabil \& Sulistyarini, 2013).

Individuals who work on shift have difficulty to adjust the sleeping schedule. Sleeping disorder is a major problem related to shift work (Wijaya et al., 2007). While in this study it was found that almost the 
majority of DM elderly in PHC Garuda was unemployed, and more than a half of respondent had a good sleep. This study found that the majority of the DM elderly in PHC Garuda had no history of other diseases which may affect sleep. The theory stated that the majority of elderly should have poor sleep quality due to DM disease, but based on the results of research shows that the condition of DM disease does not affect the quality of sleep. Based on the theory, the disease affects a person's sleep condition. Elderly with diabetes often reported a poor sleep quality and sleep duration compared with healthy elderly (Amir, 2007).

Hermawati (2010) found that light affects sleep. This is related to the production of melatonin hormones that affect the process of sleep, melatonin helps people sleep more soundly, reduce the number of sudden awakening at night, and improve the quality of sleep. Melatonin production is driven by the dark and silent environment. It is found that most of DM patient in PHC Garuda sleep with bright light environment condition. This can be one of the factors that lead to poor quality of sleep.

In this study, it was found that the majority elderly sleep with normal temperature condition in the bed room, and a half of them had a good quality of sleep. The theory stated that temperature conditions do not affect the quality of elderly sleep. In addition, other factors that affect one's sleep condition is the temperature environment. Uncomfortable environments such as moisture can also affect sleep (Potter \& Perry, 2010).

Drinks contain caffeine and alcohol would disrupt sleep (Asmadi, 2008). This study found that more a half participants consumed caffeine, both tea and caffeine, and a half of them had a good quality of sleep. This can be one of the factors that lead to poor quality of elderly sleep. The majority of elderly participants had a good sleep quality. The subjective evaluation of sleep quality is a brief evaluation of a person's sleep about whether the sleep is very good or very bad (Saputri, 2009).

The elderly sleep latency in this study was almost half as high as 0 and 1 score. This appeared that the symptoms that appear due to diabetes mellitus and can be a factor that affects the low quality of sleep in elderly. Diabetic patients suffering from RLS are more likely to report poor sleep quality, have longer sleep latency and poor sleep efficiency compared with the control of diabetes without RLS (Cuellar, 2008). This study found that more than a half elderly had sleep duration 6-7 hours. The symptoms that appear due to diabetes mellitus suffered and can be a factor that affects low quality sleep. Sleep apnea can cause disturbed sleep, and decreased total sleep time (Balachandran, 2014).

The efficiency of everyday elderly sleep in this research was mostly $>85 \%$. The theory stated that the majority of elderly have a poor sleep efficiency, but this study results showed that the disease conditions experienced do not affect the efficiency of elderly sleep. Diabetic patients suffering from RLS are more likely to report poor sleep quality, have longer sleeping and poor sleep efficiency compared with diabetes control without RLS (Cuellar, 2008). The elderly sleep disorder in this study is almost entirely present in score 1 of 37. This is one of the consequences of the symptoms that appear due to diabetes mellitus and can be a factor that affects the low quality of elderly sleep. The sleep apnea causes sleep disturbance, and decreased the duration of sleep (Balachandran, 2014).

None of the respondents in this study consumed sleeping pills. This finding in line with the theory that drug consumption is not too much affect the quality of sleep. Sedative drugs have an effect on sleep disturbance at REM stage. Therefore, after taking a sedative-containing drug, over time a person faced the difficulty of sleeping, for example frequency awakening in the middle of the night and difficulty falling back asleep, these would have a direct impact on the quality of sleep (Buysse et al., 1989; Modjod, 2007). This study found almost a half of respondents had dysfunction of daytime activities. A person with poor sleep quality may show sleepiness during daytime activities, lack of enthusiasm or attention, sleep during the day, fatigue, depression, susceptibility to distress, and decreased ability to move (Buysse et al., 1989; Modjod, 2007).

Nurses are the first care givers who may be able to provide information regarding the need for a good sleep quality to patients, it 
Citra Windani Mambang Sari : Sleep Quality of Elderly with Diabetes Mellitus

because nurses are the first patient's contact in the health services. Nurses' roles include as an educator to prevent a poor sleep quality in elderly with DM, by providing information. The information includes to keep the quality of sleep remain good, they need to sleep in the dark, warm room temperature and avoiding to consume caffeine before sleep.

\section{Conclusion}

This study found that more than a half of elderly who participated in this study had a poor sleep quality. All elderly in this study had a sleep disorder and some elderly had unhealthy behavior related to sleep quality. The results of this study expected to be a source of knowledge about some elderly behavior that deteriorates the quality of sleep, and can be a motivation for DM elderly to pay more attention to the quality of sleep by doing things that can maintain good sleep quality

This study is also expected to help community nurses in providing health education material related to maintaining a good sleep quality. The results of this study can be used as a reference and preliminary data for further researchers, especially regarding the quality of sleeping in elderly who only have DM disease. So it can be determined the sleep quality results only from DM disease.

\section{References}

Amir, N. (2007). Gangguan tidur pada lanjut usia diagnosis dan penatalaksanaan. Cermin Dunia Kedokteran, 157, 196-206.

Asmadi. (2008). Konsep dasar keperawatan. Jakarta: EGC.

Balachandran, J., Mokhlesi, B., \& Shear, T. (2014). Risk of sleep apnea in hospitalized older patients. Journal of Clinical Sleep Medicine. University of Chicago. Chicago.

Balitbang Kemenkes RI. (2013). Riset kesehatan dasar; RISKESDAS. Jakarta: Balitbang Kemenkes RI.
Black, M., \& Hawks, H. (2008). Medical surgical nursing: Clinical management for positive outcome ( $8^{\text {th }} \mathrm{Ed}$.), 405-415. Saunders Elsevier. St. Louis. Missouri.

Buysse, D. et al. (1998). The pittsburh sleep quality indeks: A new instrument for psychiatric pactice and research. Psyciatric research. Ireland: Elsevier Scientific Publishers.

Cuellar, N., \& Sarah, J. (2008). A comparison of glycemic control, sleep, fatiq and depression in type 2 diabetes with and without restless legs syndrome. Journal of Clinical Sleep Medicine, 4(1), 50-56.

Cunha, M., Zanetti, M., \& Hass, V. (2008). Sleep quality in type 2 diabetics. Rev Latinoam Enfermagem Setembrooutubro, 850-855. Diperoleh dari http://www.eerp.usp.br/rlae/

Dewi, P. (2011). Kualitas tidur dan faktorfaktor gangguan tidur pada penderita diabetes mellitus di Wilayah Kerja Puskesmas Medan Johor. Skripsi. USU.

Hermawati. (2010). Hubungan antara kualitas tidur dengan indeks prestasi mahasiswa reguler FIK UI. Riset. Universitas Indonesia, Jakarta.

Hidayat, A. (2007). Pengantar kebutuhan dasar manusia: Aplikasi konsep dan proses keperawatan. Jakarta: Salemba Medika.

IDF. (2015). IDF diabetes atlas. Diperoleh dari http://www.idf.org/atlasmap/atlasmap/.

Kerlinger. (2007). Asas-asas penelitian behaviour (Edisi 3, Cetakan 7). Yogyakarta: Gadjah Mada University Press.

Kozier, B., Glenora, B., \& Shirlee, J. (2011). Fundamental keperawatan: Konsep, proses, dan praktik (Edisi 2), 660-669. Jakarta: EGC.

Modjod, D. (2007). Insomnia experience, management strategies, and outcomes in ESRD patients undergoing hemodialysis. Tesis. Mahidol University.

Nabil, I., \& Sulistyarini, D. (2013). Perbedaan 
Citra Windani Mambang Sari : Sleep Quality of Elderly with Diabetes Mellitus

kualitas tidur lansia yang tinggal bersama keluarga dengan lansia di PSTW. Jurnal Ners dan Kebidanan Indonesia. ISSN 2354-7642.

Potter, P., \& Perry, A. (2010). Fundamental keperawatan (Buku 3, Edisi 7). Jakarta: Salemba Medika.

Saputri, D. (2009). Hubungan antara sleep hygiene dengan kualitas tidur pada lanjut usia di Dusun Sendowo, Kelurahan Sinduadi, Mlati, Sleman, Yogyakarta. Skripsi. Universitas Gadjah Mada, Yogyakarta

Smyth, C. (2012). The pittsburgh sleep quality index (PSQI). Diperoleh dari, http:// consultgerim.org/uploads/File/trythis/ trythis61.pdf.

Song, J., \& Kang, C. (2013). Antimicrobial resistance in Asia: Current epidemiology and clinical implications. Infection and Chemotherapy, 45(1). 22-31.
Surani, S., Brito, V., \& Ghamande, S. (2015). Effect of diabetes mellitus on sleep quality. United States: World Journal of Diabetes. Texas AM University.

Umbarwanto, Susilo \& Aniroh. (2016). Gambaran kualitas tidur pasien diabetes mellitus tipe 2 di RSUD Ungaran Kabupaten Semarang. STIKES Ngudi Waluyo Ungaran Semarang.

Van, M., Wijkstra, H., \& Debruyne, F. (2010). The role of nocturia in the quality of life of men with lower urinary tract symptoms. BJU, 105, 1141.

Wijaya, S.L., \& Suparniati, E. (2007). Hubungan shift kerja terhadap gangguan tidur dan kelelahan kerja perawat Instalansi Rawat Darurat Rumah Sakit dr. Sardjito Yogyakarta. Diperoleh dari http://ilib.ugm. ac.id/jurnal/download.php?dataId=39. 